\title{
Investigation of sulphate origins in the Jeffara aquifer, southeastern Tunisia: A geochemical approach
}

\author{
Samir Kamel*, Mohamed Ben Chelbi and Younes Jedoui \\ Institut Supérieur des Sciences et Techniques des Eaux de Gabès, Cité Erriadh. Campus Universitaire, \\ Zrig. Gabès 6072, Tunisia. \\ *Corresponding author.e-mail: samir.kamel@isstegb.rnu.tn
}

The chemical composition of groundwater within the multilayer Jeffara aquifer and the detailed analysis of saturation indices enables identification of the origin of mineralization and hydrogeochemical processes occurring in groundwater. It has been demonstrated that groundwater is mainly characterized by a $\mathrm{Ca}-\mathrm{Mg}-\mathrm{SO}_{4}-\mathrm{Cl}$ water type. Geochemical pattern is controlled by the dissolution of evaporites, largely abundant in the study area and incongruent dissolution of dolomite. Gypsum, anhydrite, mirabilite and thenardite have been examined as potential sources of sulphate dissolved in groundwater. Since Jeffara groundwater is recharged by the Continental Intercalaire (CI) geothermal water, water temperature decreases from the CI to the Jeffara aquifer. Solubility of the majority of minerals is modified by this change in temperature and thus a mixing process of thermal and non-thermal waters was examined.

\section{Introduction}

Water analyses carried out in the Jeffara basin provide an opportunity to recognize the relationship between evaporites bearing different sedimentary rocks and a mechanism that leads to the salinization of groundwater.

The Jeffara basin is the largest, coastal type basin in central North Africa, and shared between Tunisia and Libya. It covers about $15,000 \mathrm{~km}^{2}$ drainage area running from southeast Tunisia, near Gabes, to north-west Libya, east of Tripoli and declining gradually, towards the Mediterranean Sea. The present study is focused on the northern part of the Jeffara plain known as 'the Jeffara of Gabes' (figures 1 and 2).

Jeffara basin encloses numerous sebkhas (saline lakes), but they are progressively drained by the expanded cities. Gypsum is by far the most abundant calcium sulphate mineral that forms under normal sedimentary conditions (Kinsman 1966). Indeed, it occurs in the study area, in different forms:

(1) Alternating with dolomite, marl and gypsum in subsiding deposit up to $800 \mathrm{~m}$ thickness in northern Chott Chain (figure 1).

(2) Interbedded in massive and compact deposit of terraces. In the case where erosion affected the upper part of the terrace, gypsum increased more consistently and changes in gypsum crust were observed (Swezey 2003). These gypsum layers of one to several metres thickness, in the deposits forming the terraces, were marked on the banks of Sourag, Zerkine Wadis and in the Oum Zessar and Zerkine Sabkhat (figure 1).

In southern Tunisia, thousands of exploration and development oil boreholes have identified an

Keywords. Evaporite dissolution; gypsum/anhydrite; mirabilite/thenardite; saturation state; mixing process. 


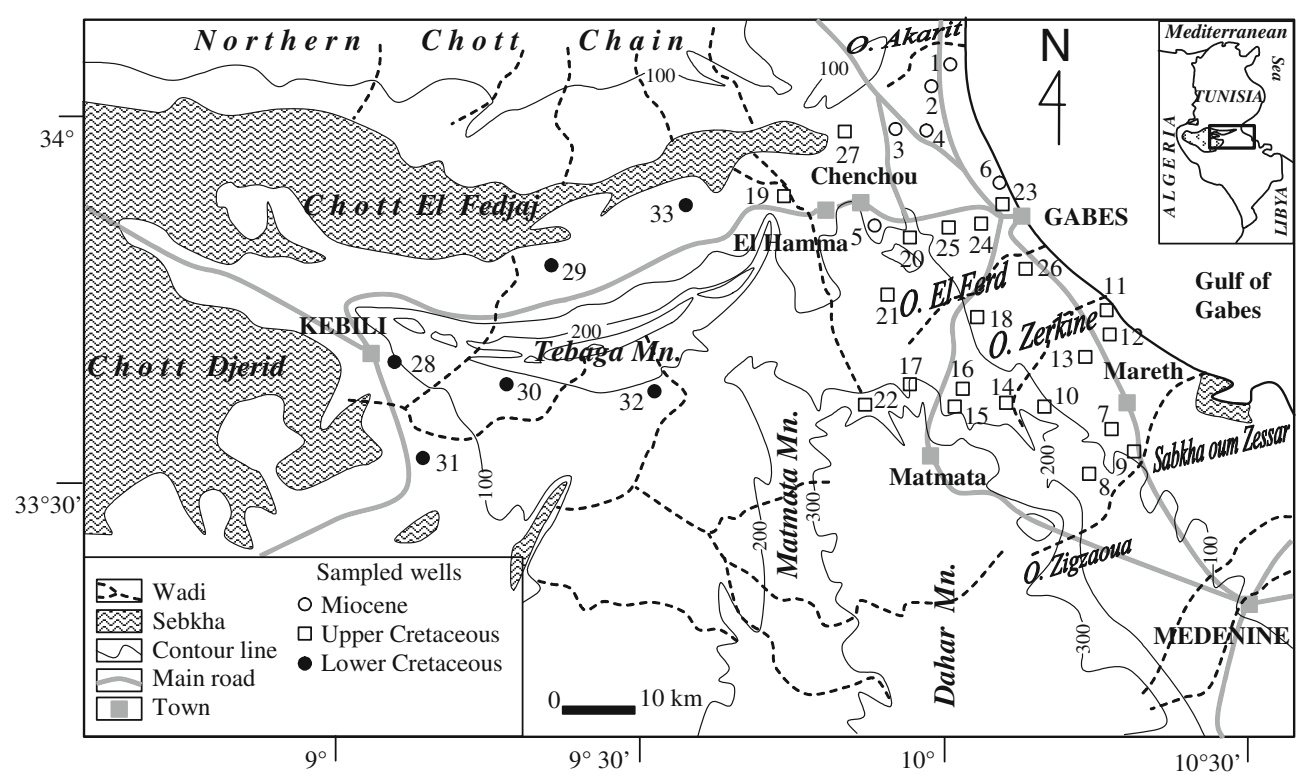

Figure 1. Study area in south-eastern Tunisia with geographic features and location of sampled wells. Jeffara plain is surrounding by low reliefs not exceeding $500 \mathrm{~m}$ height and the Saharan desert with large chotts.

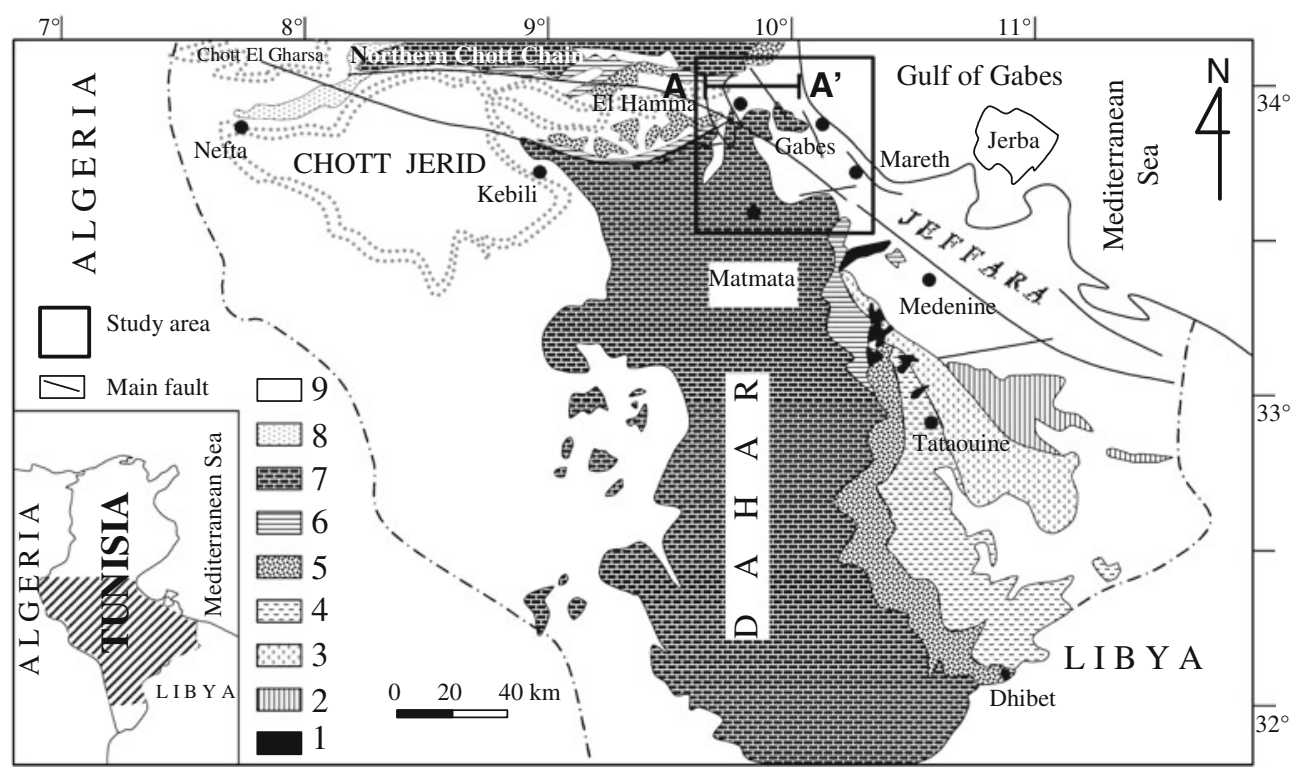

Figure 2. Simplified geological map (after Benton et al. 2000) with cross-section AA' location 1: Permian, 2: Triassic, 3: Lias, 4: Dogger, 5: Malm, 6: Vraconian (mid-late Albian), 7: Late Cretaceous, 8: Mio-Pliocene, and 9: Pliocene-Quaternary. The evolution of outcrops age is from southeast to northwest.

important evaporitic formation (gypsum/ anhydrite) related to deposits of Upper TriassicLower Jurassic (Bir Ghanem Formation), Upper Jurassic (Abreghs Formation) and to the Lower Cretaceous ages (Zeggab Formation) (Mamou 1990; Bouaziz 1995).

The Gabes region is characterized by arid to semi-arid climate influenced by dry and hot air masses coming from the desert and by humid air masses coming from the Mediterranean Sea (Mekrazi 1975). Precipitation is rare and irregular, occurring mostly from October to January. The annual average precipitation is of $189 \mathrm{~mm}$ and mean annual temperature is $21^{\circ} \mathrm{C}$. The drainage network consists of the non-perennial Wadis which collects runoff water from the northern Chott Chain, Matmata and Dahar range. Potential evapotranspiration is about $2760 \mathrm{~mm}$ per year 
(Abidi 2004) and most of the rainwater is lost by evaporation.

Available surface water is insufficient for current domestic, industrial and agricultural needs of the region. Consequently, groundwater constitutes the main water resource in the Jeffara plain.

About $86 \%$ of Jeffara of Gabes total domestic, industrial and agricultural water demands, estimated as 104 million $\mathrm{m}^{3}$ /year, is covered by groundwater abstraction (DGRE 2009). Original conditions were those of a fully saturated artesian basin even some 100 years ago with numerous springs occurring across the plain.

Hundreds of shallow and more than 500 deep wells were drilled to meet the rapidly growing demand for water (Abidi 2004).

Earlier work carried out in the Jeffara plain consists of hydrochemical and statistical studies (Kettata et al. 2009) and quantification of regional groundwater flow between continental Intercalaire (CI) and Jeffara aquifers using stable isotope balance (Trabelsi et al. 2009). There has been limited attempt to study the mechanisms that contribute to water mineralization. Hence, the main objective of this study is to integrate major and minor ion geochemistry with the saturation state of the evaporites in order to identify both the hydrochemical processes and sulphate sources, in the Jeffara aquifer.

Special attention is paid to the behaviour of the hydrated and anhydrous evaporites under the progressive cooling water of the geothermal CI regional flow during its ascent, recharging the Jeffara groundwater. Influence of ascending inflow of water from the geothermal CI recharging the Jeffara aquifer and its cooling along the flow was considered.

\section{Study area}

The study area is located in the southeastern part of Tunisia and lies approximately between longitudes $9^{\circ} 30^{\prime}$ to $10^{\circ} 30^{\prime} \mathrm{E}$ and $33^{\circ} 30^{\prime}$ to $34^{\circ} \mathrm{N}$. It extends from the Mediterranean Sea coast in the east to the Matmata and Dahar in the west, which is the mountain range separating plain of the Jeffara from the Saharan desert. The study area is limited in the north by the northern Chott Chain. The southern limit is constituted by Zigzaoua Wadi, near Mareth city (figure 1).

\section{Geology}

A simplified geological map of southern Tunisia and a representative lithostratigraphic chart are shown in figures 2 and 3, respectively. Geology of the Jeffara plain consists of a sedimentary succession extending from Permian to Quaternary, with sedimentary gaps from Paleocene to Eocene and during the Lias stage (Mamou 1990). The continental formations of Lower Cretaceous (Neocomian, Barremian, Aptian and Albian) contain the CI, which is located in the Chott el Fedjej and Kebili regions, western part of the study area (figure 1).

In the Jeffara of Gabes, the Upper Cretaceous is represented by the Cenomanian, the Turonian and the Lower Senonian, which is divided into two distinct entities: the marl/gypsum Senonian and the limestone Senonian (Rouatbi 1967). Mio-Pliocene is formed by continental material; gypsum marl and sands.

Quaternary is represented by the Lower Villafranchien-Pleistocene, the Upper Pleistocene and the Holocene (Ben Ouezdou 1983). It is mainly formed by conglomerates, marl and gypsum, which generally repose uncomfortably on the Senonian limestone (Mhamdi et al. 2011).

The Jeffara basin has undergone a complex and polyphase structural history since the Carboniferous (Ben Ayed 1986). It has been affected by multiple episodes of tectonism, including a late Paleozoic collision with Laurasia and subsequent early Mesozoic rifting associated with the opening of the Tethyan Ocean (Gabtni et al. 2006). Caledonian (Devonian), Hercynian (Carboniferous), Austrian (Early Cretaceous) and Alpine (Late Cretaceous-Early Eocene) on the Jeffara area has been the production of a large sedimentary basin. During Mesozoic extensional tectonics, there was an episode of northwestward tilting of the region, resulting in the superposition of a preand post-tilting Mesozoic basin on eroded remains of the Paleozoic basin. The alpine orogeny affected the basin with less intensity than it did in the Atlas Mountains to the north; however, several Hercynian-aged normal faults were locally inverted (Gabtni et al. 2006).

\section{Hydrogeology}

This study is focused on southern Tunisia which forms a part of the northern Saharan sedimentary basin which contains two important aquifer systems extending over an area of $780,000 \mathrm{~km}^{2}$ (Guendouz et al. 2003): The CI is overlain by the Complexe Terminal (CT). Lateral continuation of the $\mathrm{CT}$ in the coastal plain of Tunisia and Libya forms the Jeffara aquifer (OSS 2003). Although lithologically similar, the Jeffara and CT aquifer systems are hydrogeologically and geochemically independent with distinct recharge mechanism and sources, groundwater flow, recharge sources and chemistry (Trabelsi et al. 2009). 


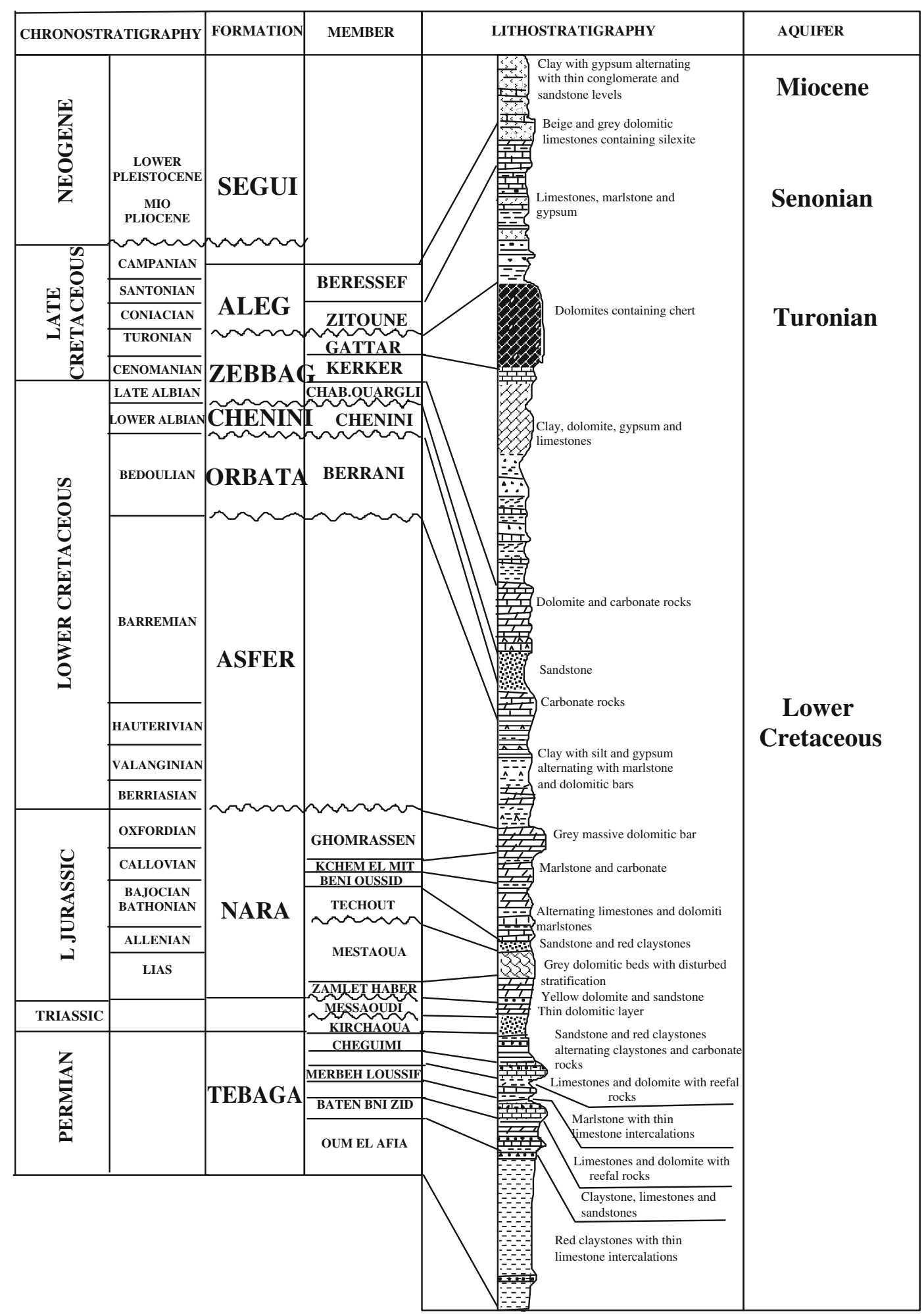

Figure 3. Lithostratigraphic column of southern Tunisia (modified after Mhamdi et al. 2011). Miocene and the Lower Cretaceous aquifers are hosted in sandy formation, the Upper Cretaceous aquifer, in fissured limestone. All are associated with gypsum layers.

Numerous geologic and hydrological studies carried out in southeast Tunisia (Rouatbi 1967; Ben Baccar 1982; Mekrazi 1975; Bouaziz et al. 2002; Abidi 2004; Kettata et al. 2009; Trabelsi et al.
2009) have been important in defining the architecture of the Jeffara and boundaries of the potential reservoir. From a structural point of view, the area is represented by horst and graben 


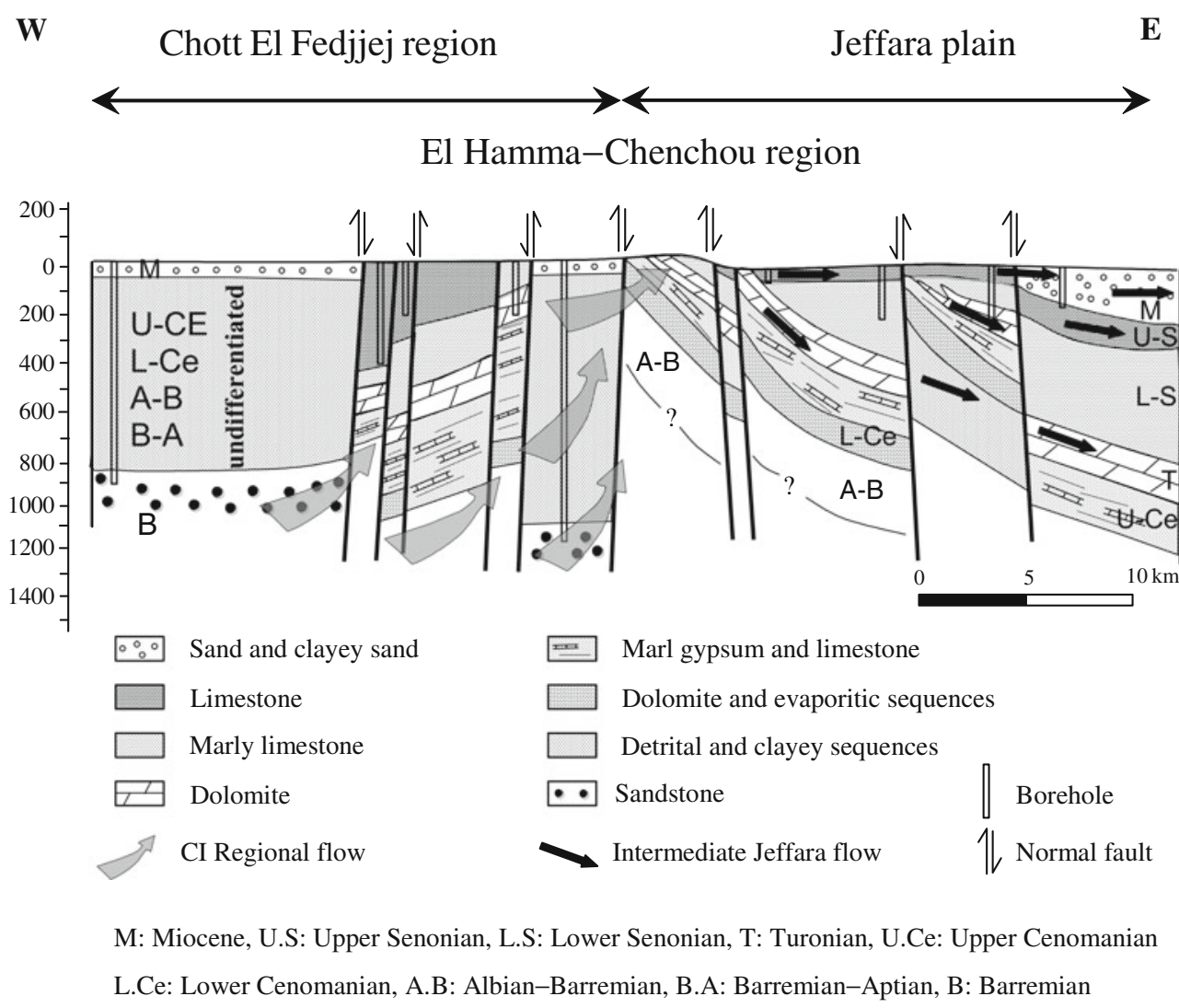

Figure 4. Hydrogeological cross-section $\mathrm{AA}^{\prime}$, as indicated in figure 2, showing the main flow from CI recharging the Jeffara aquifer.

structures with a distensive tectonic style generated during the Cretaceous. In southern Tunisia, the general tectonic lineament strikes NW-SE with conjugated NE-SW faults that lead to the discharge of CI hot water in the Jeffara aquifer (Bouri et al. 2008).

The Jeffara aquifer system is characterized by the variability of lithology and thickness of waterbearing horizons. From the bottom to the top, three hydrostratigraphic units are distinguished (figure 4).

\subsection{The Turonian aquifer}

The Turonian carbonates constitute the principal water-bearing formation in the region of Matmata, El Hamma and Chenchou. The aquifer consists of dolomites and fissured limestones, whose thickness does not exceed $50 \mathrm{~m}$ (Rouatbi 1967) (figure 3). Although, its extent is limited, the Turonian aquifer is characterized by high transmissivity, generally around $0.1 \mathrm{~m}^{2} / \mathrm{s}$, exceptionally reaching $1.2 \mathrm{~m}^{2} / \mathrm{s}$ in the Chenchou area where the crustal deformation is particularly intense. The Jeffara basin is strongly affected by tectonism, which links three different water-bearing horizons into a single hydraulic structure (figure 4).

\subsection{The Senonian aquifer}

The principal aquifer of Gabes consists of Senonian limestone which is abstracted by a large number of boreholes. The Senonian formation consists of two stratigraphic units. The lower one, formed by marl and gypsum, with a thickness of approximately $50 \mathrm{~m}$, is known as 'horizon B'. This level is covered by a limestone level (horizon A) characterized by a variable thickness, up to $500 \mathrm{~m}$ (figures 3 and 4). These water-bearing formations are strongly fissured, with the transmissivity ranging from $0.910^{-3}$ to $34510^{-3} \mathrm{~m}^{2} / \mathrm{s}$. All water-bearing formations of the Jeffara plain are hydraulically connected through the existing faults.

\subsection{The Miocene aquifer}

The part of Jeffara aquifer located in northern Gabes (figure 4) is formed by Miocene continental 


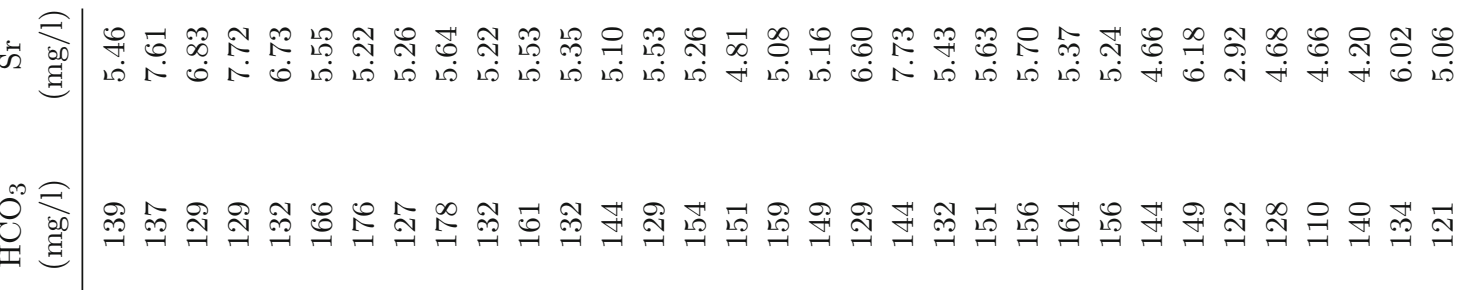

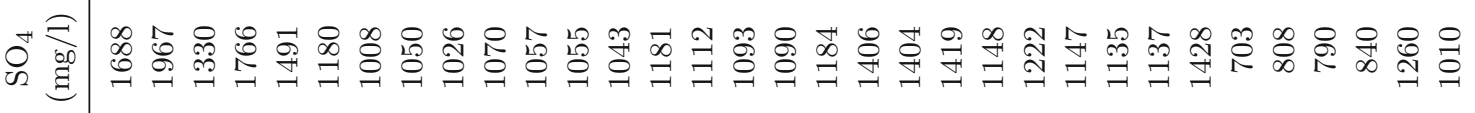

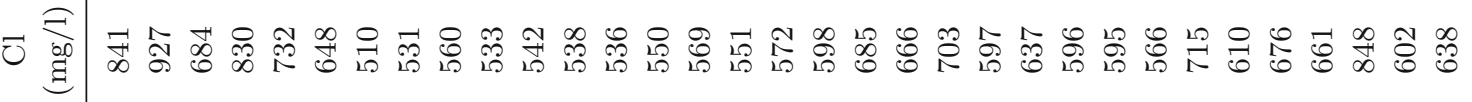

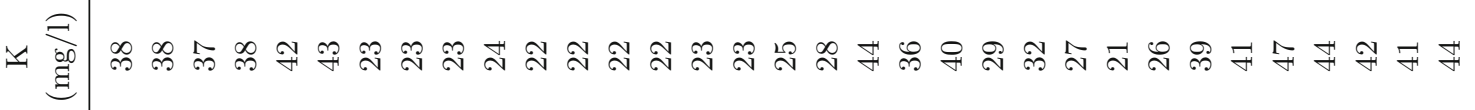

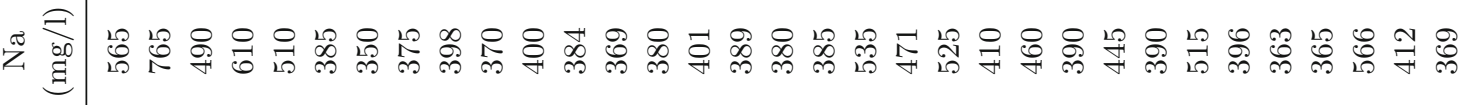

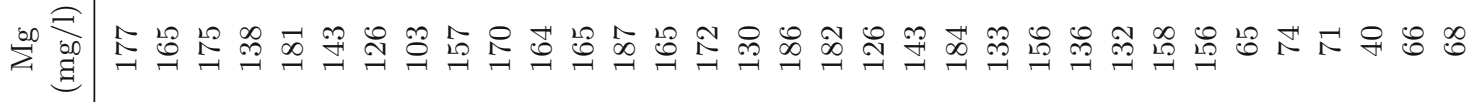

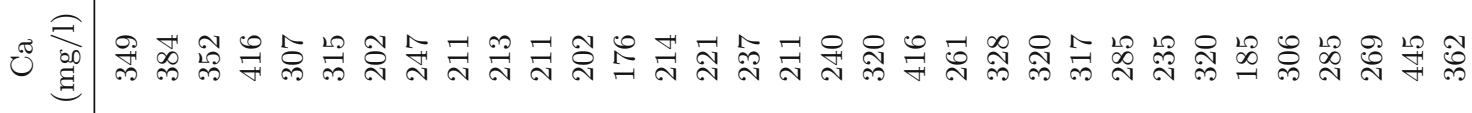

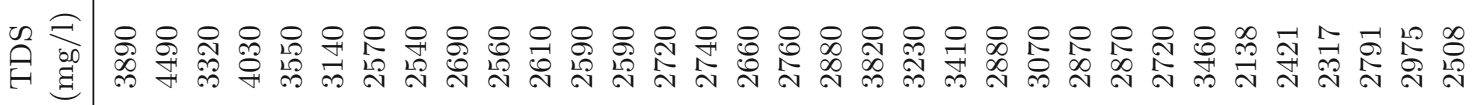

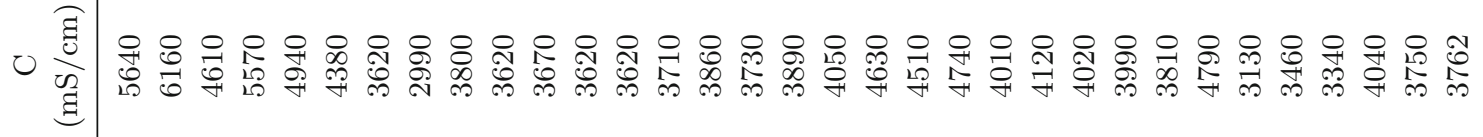

स゙

แ艹

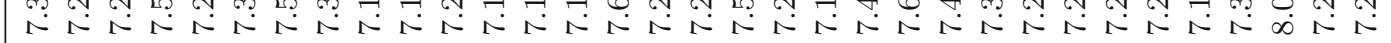

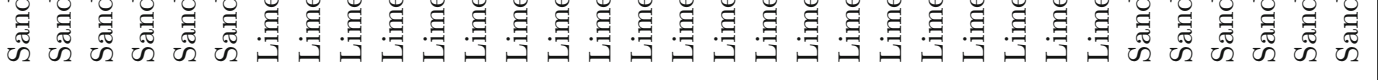


deposits which consist of red clays with intercalation of conglomeratic and sandy levels produced after the post-Cretaceous erosion (Bouaziz 1995; Benton et al. 2000). The thickness of these sand deposits increases from 25 to $80 \mathrm{~m}$ towards the sea. They are characterized by fine granulometry and permeability ranging from $2 \times 10^{-5}$ to $4 \times$ $10^{-4} \mathrm{~m} / \mathrm{s}$.

Hydraulic continuity between the CI and the Jeffara aquifer has been demonstrated through several hydrodynamic and isotopic studies (Gonfiantini et al. 1974; Mamou 1990; OSS 2003; Abidi 2004; Trabelsi et al. 2009). Hydraulic contact between the CI and Jeffara aquifers is suggested by the differences in hydraulic heads. The hydraulic heads of the CI aquifer indicate west-east flow (figure 4), in the direction of El Hamma-Chenchou region, with the hydraulic head of about $200 \mathrm{~m}$ (OSS 2003). On the other hand, the Jeffara aquifer shows a general southwest-northeast flow from the Matmata relief and El Hamma region towards the Mediterranean Sea, in accordance with the plain structure (figure 4). Near El Hamma faults, the hydraulic head is around $50 \mathrm{~m}$, which is explained by the rise of CI groundwater through El Hamma faults (figure 2) assuring $2.12 \mathrm{~m}^{3} / \mathrm{s}$ recharge of the Jeffara aquifer (Mamou and Kassah 2002).

In Matmata region, Turonian and Senonian outcrops facilitate recharge of the Jeffara aquifer, estimated at $0.96 \mathrm{~m}^{3} / \mathrm{s}$ (Mamou and Kassah 2002). Discharge amounts to $5.25 \mathrm{~m}^{3} / \mathrm{s}$, including artificial discharge by pumped wells $\left(4.53 \mathrm{~m}^{3} / \mathrm{s}\right)$, the rest flows naturally into the Gulf of Gabes. Balance deficit is about $2 \mathrm{~m}^{3} / \mathrm{s}$.

\section{Analytical methods}

A representative set of samples was collected from 33 active water supply boreholes/wells penetrating different lithological units in the Jeffara and the CI aquifers, during May 2009 (table 1 and figure 1). Temperature, electrical conductivity and $\mathrm{pH}$ were measured in the field. Samples of groundwater were kept in a refrigerator upon collection. Major and minor element determinations were carried out after filtering of samples through $0.45 \mu \mathrm{m}$ filter. Geochemical analyses were carried out in the 'laboratoires du Groupe Chimique de Gabès'. Calcium and magnesium dosing was carried out by titration with EDTA. Sodium and potassium were measured using a flame photometer. Chloride and sulphate concentrations were determined using the Mohr and gravimeters methods, respectively. The total alkalinity (as $\mathrm{HCO}_{3}$ ) was determined by titration with 0.01 or $0.1 \mathrm{M} \mathrm{HCl}$ and methyl orange as indicator. Strontium and duplicate analyses were done (except for $\mathrm{HCO}_{3}$ ) in the 'Institut Superieur des Sciences et Techniques des Eaux de Gabès, Tunisia' using HPLC Bishoff Lanbda 1010 type and an ionic liquid chromatography Metrohm 850 Professional IC type equipped with auto sampler, 858 Professional Sample Processor Metrohm type. Charge balance for all samples including strontium data is less than $5 \%$.

\section{Results and discussion}

\subsection{Physico-chemical data}

Samples collected from the CI are characterized by high temperature varying from $56^{\circ}$ to $70^{\circ} \mathrm{C}$. Considerably lower temperature, ranging from $23^{\circ}$ to $30^{\circ} \mathrm{C}$ was detected in the Miocene horizon, with the exception of one well (No. 9), where measured temperature was $37.8^{\circ} \mathrm{C}$. Samples collected from limestone level of the Jeffara display an intermediate position between $24^{\circ}$ and $41.6^{\circ} \mathrm{C}$; while temperature of the Jeffara groundwater varies widely from $23^{\circ}$ to $42^{\circ} \mathrm{C}$. Independent of the borehole depth, the water temperature is the highest in the El Hamma region, which points to some inflow of groundwater from the CI aquifer through the network's most developed fault of the plain (figure 4).

The conductivity of CI groundwater samples ranges from 3130 to $4040 \mu \mathrm{S} / \mathrm{cm}$. Conductivity of the Jeffara aquifer varies between 2990 and $6160 \mu \mathrm{S} / \mathrm{cm}$. The highest values are

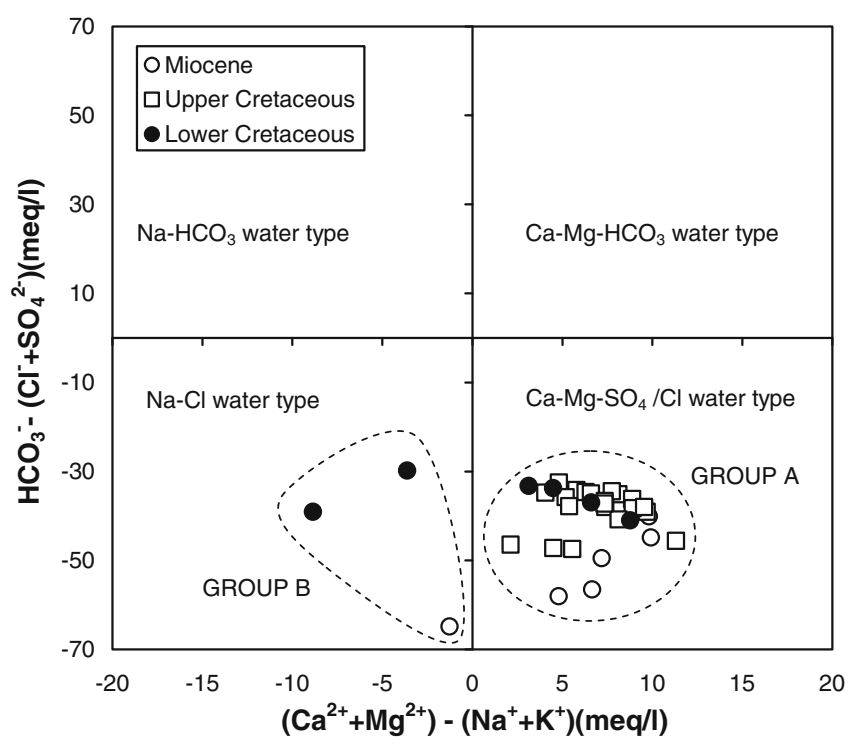

Figure 5. Chadha diagram showing the water type of the groundwater samples. Two sub-groups are identified in the $\mathrm{Ca}-\mathrm{Mg}-\mathrm{SO}_{4} / \mathrm{Cl}$ water type. 
measured in samples from the Miocene sands and limestone of El Hamma region. The salinity of Miocene sands aquifer in northern Gabes increases with time (Charfi 2004). High groundwater abstraction in this region to ensure industrial needs including water for phosphate treatment, leads to formation of the depression cone, which facilitates leakage of saline water from the local shallow saline drainage aquifer formed by return flow irrigation. In the El Hamma region, the salinity of groundwater is abnormally high, suggesting that saline water originated from Chott El Fedjaj.

\subsection{Water types}

Chemical composition of the analysed groundwater samples is plotted on the Chadha diagram (Chadha 1999), which is a somewhat modified version of the Piper diagram and the expanded Durov diagram; the difference is that the two equilateral triangles are omitted (Chadha 1999). The plot of the CI and Jeffara groundwater samples in the Chadha diagram (figure 5) presents two groups; the alkaline earth-rich group (Group A) and the alkali metals-rich group (Group B). The first group, which comprised the majority of the analysed samples, showed that the alkaline earth $(\mathrm{Ca}+\mathrm{Mg})$ exceeded the alkali metals $(\mathrm{Na}+\mathrm{K})$ and that the strong acids $\left(\mathrm{Cl}+\mathrm{SO}_{4}\right)$ exceeded the weak acid $\left(\mathrm{HCO}_{3}\right)$. The second group, which included only two samples from the CI and a single sample from the Miocene aquifer, revealed that $(\mathrm{Na}+\mathrm{K})$ was superior to $(\mathrm{Ca}+\mathrm{Mg})$ and the strong acids $\left(\mathrm{Cl}+\mathrm{SO}_{4}\right)$ exceeded the weak acid $\left(\mathrm{HCO}_{3}\right)$. Group A plots on the field of the $\mathrm{Ca}-\mathrm{Mg}-\mathrm{SO}_{4} / \mathrm{Cl}$ water type and group $\mathrm{B}$, on the field of $\mathrm{Na}-\mathrm{Cl}$ water type.

\subsection{Major ions geochemistry}

Dominant cations are mainly sodium and calcium, while dominant anions are sulphate and chloride. Bivariate diagrams of major elements are used in order to separate different mechanisms that contribute to groundwater salinization. In particular, sodium is positively correlated with chloride and sulphate with calcium (figure 6a, b). These relations indicate the possible dissolution of halite, gypsum and/or anhydrite-bearing rocks relatively abundant, especially in the shallow levels of the Jeffara groundwater (less than $100 \mathrm{~m}$ depth).

However, the plot of $\mathrm{SO}_{4}$ versus $\mathrm{Ca}$ (figure $6 \mathrm{~b})$, drawn for the Jeffara groundwater samples, shows a relative $\mathrm{Ca}$ depletion, probably related to additional source of sulphate releasing from evaporites horizons, abundant in the sandy Miocene formation.

Analyses of minor elements indicate significant enrichment of strontium (from 2.92 to $7.73 \mathrm{mg} / \mathrm{l}$ ). $\mathrm{Sr}$ shows a linear relationship with both $\mathrm{SO}_{4}$ and $\mathrm{Ca}$ (figure 7a, b). Probable sources of strontium are celestite $\left(\mathrm{SrSO}_{4}\right)$ dissolution and/or dissolution of gypsum/anhydrite containing trace concentrations of this element. Indeed, waters with high strontium and sulphate concentrations are undersaturated with respect to celestite, making dissolution possible (Edmunds et al. 1997; Kamel et al. 2005).

In the Jeffara waters, $\mathrm{SI}_{\text {celestite, ranges from }}$ -0.953 and -0.385 (table 2). None of the waters are undersaturated with respect to celestite, making the second assumption more plausible.

Mean $\mathrm{SI}_{\text {celestite }}(-0.607)$, close to mean $\mathrm{SI}_{\text {gypsum }}$ $(-0.455)$, reinforce trace inclusion of celestite in gypsum.

Although Jeffara waters are unsaturated with respect to strontianite $(\mathrm{SrCa}) \mathrm{CO}_{3}$, with a mean
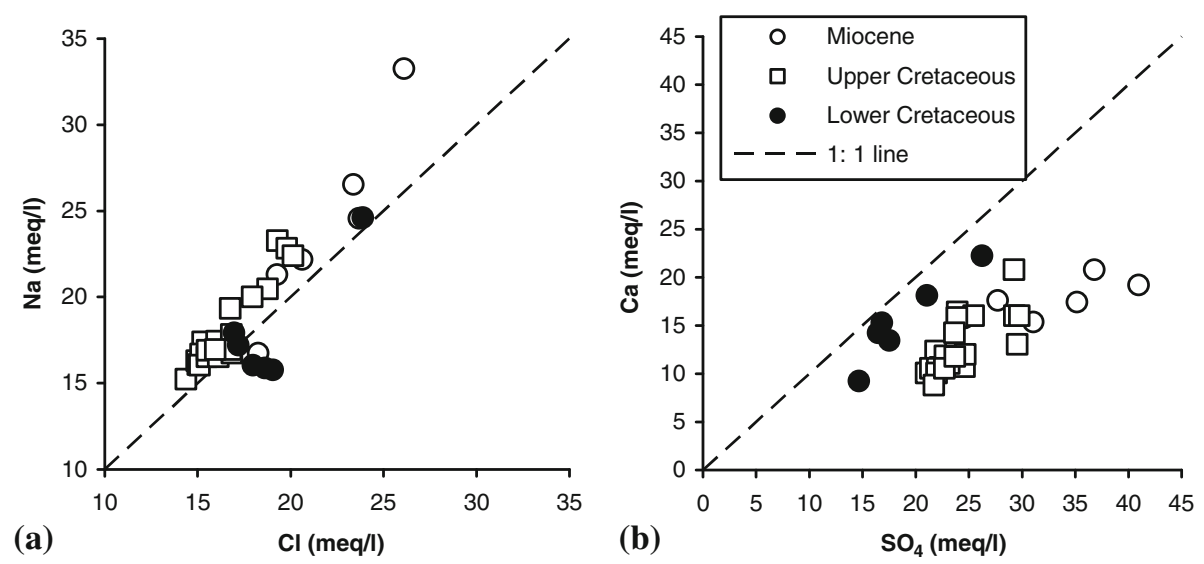

Figure 6. Bivariate diagrams between major elements: (a) $\mathrm{Na} / \mathrm{Cl}$ and (b) $\mathrm{Ca} / \mathrm{SO}_{4}$, highlighting positive correlation between sodium and chloride and calcium deficiency. 

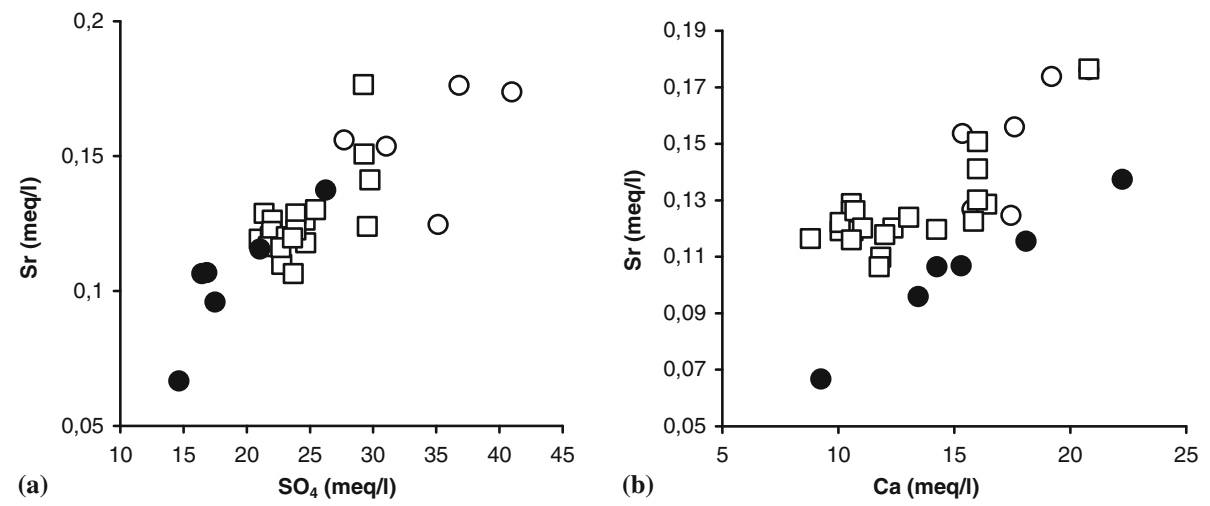

Figure 7. Relationships between (a) $\mathrm{Sr} / \mathrm{SO}_{4}$ and (b) Sr/Ca. Strontium is positively correlated with both sulphate and calcium, probably reflecting its association with gypsum.

Table 2. Saturation indices of main minerals involved in sulphate geochemistry.

\begin{tabular}{|c|c|c|c|c|c|c|c|c|c|}
\hline Map no. & $\mathrm{SI}_{\text {Halite }}$ & $\mathrm{SI}_{\text {Calcite }}$ & $\mathrm{SI}_{\text {Dolomite }}$ & $\mathrm{SI}_{\text {celestite }}$ & $\mathrm{SI}_{\text {strontianite }}$ & $\mathrm{SI}_{\mathrm{Gypsum}}$ & $\mathrm{SI}_{\text {Anhydrite }}$ & $\mathrm{SI}_{\text {Mirabilite }}$ & $\mathrm{SI}_{\text {Thenardite }}$ \\
\hline 1 & -5.025 & 0.131 & 0.344 & -0.551 & -1.323 & -0.283 & -0.500 & -4.618 & -5.546 \\
\hline 2 & -4.861 & 0.026 & 0.066 & -0.385 & -1.330 & -0.215 & -0.432 & -4.314 & -5.241 \\
\hline 3 & -5.166 & 0.007 & 0.084 & -0.505 & -1.343 & -0.341 & -0.558 & -4.831 & -5.760 \\
\hline 4 & -4.999 & 0.384 & 0.667 & -0.392 & -0.998 & -0.197 & -0.414 & -4.538 & -5.465 \\
\hline 5 & -5.123 & -0.032 & 0.081 & -0.478 & -1.337 & -0.361 & -0.578 & -4.741 & -5.670 \\
\hline 6 & -5.286 & 0.257 & 0.544 & -0.602 & -1.133 & -0.398 & -0.616 & -5.056 & -5.986 \\
\hline 7 & -5.419 & 0.288 & 0.745 & -0.629 & -0.934 & -0.594 & -0.811 & -5.148 & -6.079 \\
\hline 8 & -5.373 & 0.053 & 0.098 & -0.618 & -1.255 & -0.496 & -0.714 & -5.078 & -6.008 \\
\hline 9 & -5.328 & -0.089 & 0.065 & -0.611 & -1.296 & -0.591 & -0.809 & -5.056 & -5.986 \\
\hline 10 & -5.381 & -0.170 & -0.066 & -0.634 & -1.415 & -0.575 & -0.793 & -5.105 & -6.035 \\
\hline 11 & -5.340 & -0.038 & 0.188 & -0.613 & -1.253 & -0.583 & -0.801 & -5.042 & -5.972 \\
\hline 12 & -5.360 & -0.202 & -0.118 & -0.624 & -1.412 & -0.599 & -0.817 & -5.074 & -6.004 \\
\hline 13 & -5.379 & -0.221 & -0.045 & -0.649 & -1.393 & -0.663 & -0.881 & -5.115 & -6.045 \\
\hline 14 & -5.359 & -0.199 & -0.138 & -0.583 & -1.427 & -0.541 & -0.759 & -5.041 & -5.971 \\
\hline 15 & -5.321 & 0.317 & 0.898 & -0.628 & -0.941 & -0.556 & -0.773 & -5.027 & -5.957 \\
\hline 16 & -5.345 & 0.022 & 0.157 & -0.657 & -1.307 & -0.515 & -0.732 & -5.043 & -5.973 \\
\hline 17 & -5.341 & -0.030 & 0.256 & -0.650 & -1.283 & -0.583 & -0.800 & -5.085 & -6.014 \\
\hline 18 & -5.320 & 0.280 & 0.812 & -0.627 & -1.024 & -0.509 & -0.726 & -5.047 & -5.977 \\
\hline 19 & -5.127 & 0.028 & 0.029 & -0.488 & -1.302 & -0.345 & -0.562 & -4.705 & -5.634 \\
\hline 20 & -5.196 & 0.069 & 0.049 & -0.438 & -1.302 & -0.253 & -0.471 & -4.845 & -5.774 \\
\hline 21 & -5.125 & 0.074 & 0.371 & -0.575 & -1.251 & -0.437 & -0.655 & -4.726 & -5.655 \\
\hline 22 & -5.293 & 0.542 & 1.066 & -0.602 & -0.858 & -0.388 & -0.606 & -5.012 & -5.941 \\
\hline 23 & -5.219 & 0.269 & 0.599 & -0.590 & -1.116 & -0.391 & -0.609 & -4.900 & -5.829 \\
\hline 24 & -5.315 & 0.269 & 0.543 & -0.620 & -1.137 & -0.400 & -0.618 & -5.052 & -5.982 \\
\hline 25 & -5.258 & 0.096 & 0.231 & -0.628 & -1.275 & -0.443 & -0.661 & -4.934 & -5.864 \\
\hline 26 & -5.337 & -0.002 & 0.265 & -0.681 & -1.341 & -0.529 & -0.746 & -5.052 & -5.982 \\
\hline 27 & -5.126 & 0.085 & 0.232 & -0.521 & -1.273 & -0.350 & -0.567 & -4.743 & -5.672 \\
\hline 28 & -5.277 & -0.194 & -0.473 & -0.953 & -1.618 & -0.714 & -0.931 & -5.154 & -6.084 \\
\hline 29 & -5.280 & -0.010 & -0.266 & -0.750 & -1.449 & -0.498 & -0.715 & -5.226 & -6.156 \\
\hline 30 & -5.285 & 0.028 & -0.181 & -0.750 & -1.383 & -0.526 & -0.743 & -5.220 & -6.150 \\
\hline 31 & -4.994 & 0.797 & 1.143 & -0.784 & -0.634 & -0.539 & -0.757 & -4.817 & -5.746 \\
\hline 32 & -5.290 & 0.179 & -0.098 & -0.551 & -1.328 & -0.229 & -0.446 & -4.973 & -5.903 \\
\hline 33 & -5.304 & 0.040 & -0.273 & -0.665 & -1.446 & -0.364 & -0.582 & -5.134 & -6.063 \\
\hline
\end{tabular}

$\mathrm{SI}_{\text {strontianite }}$ equal to -1.136 , calcium can be substituted by strontium in gypsum, explaining the positive correlation between $\mathrm{Sr}$ and $\mathrm{Ca}$ (figure $7 \mathrm{~b}$ ).
Saturation state of the waters with respect to halite, gypsum/anhydrite, mirabilite/thenardite, celestite and strontianite were performed using 


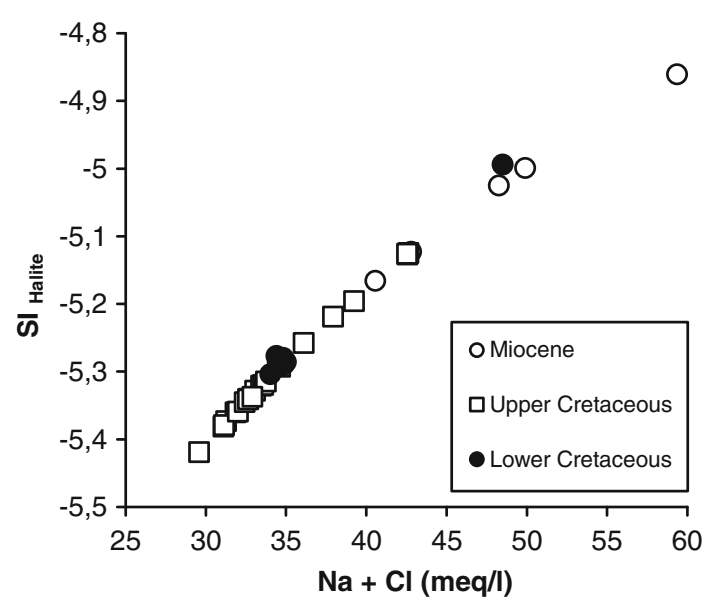

Figure 8. Plot of $(\mathrm{Na}+\mathrm{Cl})$ versus SI Halite. Undersaturation with respect to halite, reinforced halite dissolution in the three studied aquifers.

WateqF subroutine program (Plummer et al. 1992).

A saturation index of zero indicates that ion activity and solubility products are equal, and that thermodynamic equilibrium exists with the solid phase. A negative or positive index indicates undersaturation or oversaturation, respectively (Gemici and Filiz 2001).

Under ambient temperature, all water samples collected in both CI and Jeffara groundwaters are unsaturated with respect to halite $(-5.419<$ IS $<-4.861$ ) (table 2). Figure 8 shows a positive correlation between $\mathrm{SI}_{\text {halite }}$ and $(\mathrm{Na}+\mathrm{Cl})$, reinforcing halite dissolution in the referred aquifers.

The origin of sulphate, which is the most dominant cation in $90 \%$ of water samples, may be evidenced using gypsum/anhydrite and mirabilite/thenardite couples.

Sulphates may originate from either the dissolution of gypsum $\left(\mathrm{CaSO}_{4}, 2\left(\mathrm{H}_{2} \mathrm{O}\right)\right)$ /anhydrite $\left(\mathrm{Ca} \mathrm{SO}_{4}\right)$ in which they are associated with calcium, or the dissolution of mirabilite $\left(\mathrm{Na}_{2} \mathrm{SO}_{4}\right.$, $\left.10\left(\mathrm{H}_{2} \mathrm{O}\right)\right)$ /thenardite $\left(\mathrm{Na}_{2} \mathrm{SO}_{4}\right)$ when they are associated with sodium.

Figure $9(\mathrm{a}, \mathrm{b})$ shows linear positive correlation between SI of those phases and ion concentrations. Thus, the dissolution of these evaporites probably occurs in the aquifer, first because those phases are present and secondly because there are favourable conditions with their negative saturation indices.

\subsection{Water composition evolution under variable temperature conditions}

The Jeffara recharge by the deep geothermal CI is supposed to occur in the area of El Hamma Chenchou at the intersection of a network of east-west and north-south fractures.

In order to model the evolution of water chemistry more precisely, the effect of variable temperature on mineral-water equilibria has been considered.

Plots of wellhead temperature versus several elements $\left(\mathrm{Mg}, \mathrm{Na}, \mathrm{Ca}, \mathrm{K}, \mathrm{Sr}, \mathrm{Cl}, \mathrm{HCO}_{3}\right.$ and $\mathrm{SO}_{4}$ ) (figure 10) showed that concentrations of $\mathrm{Mg}, \mathrm{Sr}$ and $\mathrm{SO}_{4}$, increase with wellhead temperature, whereas $\mathrm{K}$ decreases in Miocene and Upper Cretaceous non-thermal samples. Sodium, $\mathrm{Ca}$ and $\mathrm{Cl}$ water contents, lie within the same range for both geothermal and non-thermal waters. Deep geothermal groundwaters generally contain low
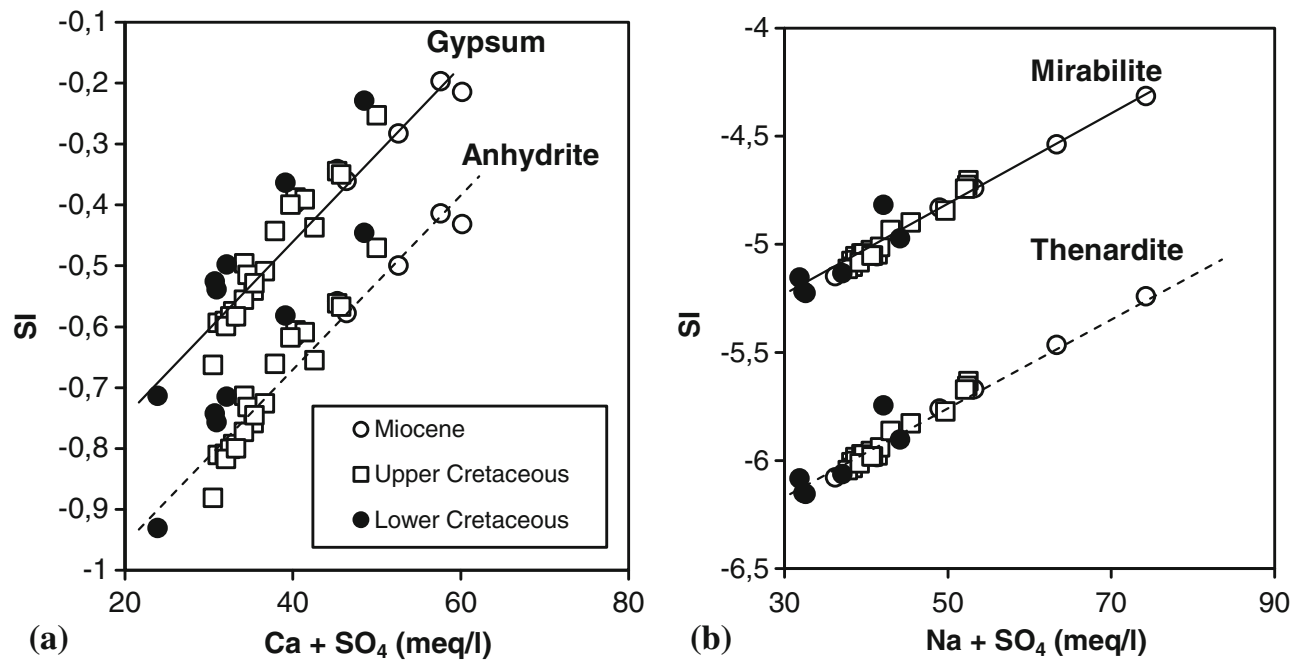

Figure 9. Minerals saturation indices (SI)/representative species relationship; $(\mathbf{a}) \mathrm{SI} /\left(\mathrm{Ca}+\mathrm{SO}_{4}\right)$ and $(\mathbf{b}) \mathrm{SI} /\left(\mathrm{Na}_{+}+\mathrm{SO}_{4}\right)$. 

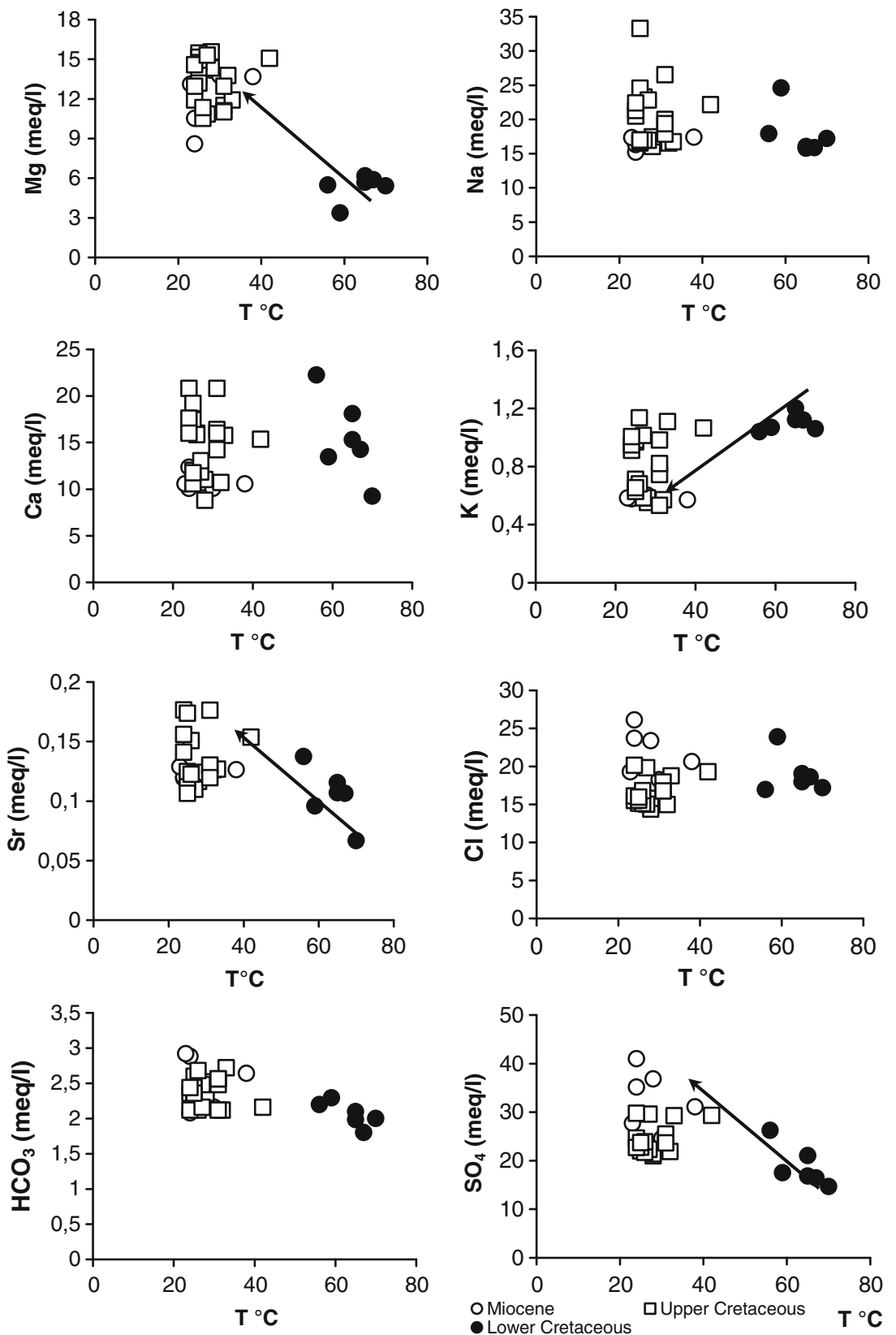

Figure 10. Major elements/temperature relationship: $\mathrm{Mg}, \mathrm{Sr}$ and $\mathrm{SO}_{4}$ increase with temperature, whereas $\mathrm{K}$ decreases in Miocene and Upper Cretaceous non-thermal samples. Sodium, $\mathrm{Ca}, \mathrm{Cl}$ and $\mathrm{HCO}_{3}$ lie within the same range for both geothermal and non-thermal waters.

$\mathrm{SO}_{4}$ content $(<50 \mathrm{mg} / \mathrm{l})$ (Nicholson 1993). Sulphate content of CI water is quite high (703$1260 \mathrm{mg} / \mathrm{l}$ ) in the study area. High sulphate concentration could be explained by buried gypsum dissolution within the lower Senonian formation.

The relationship between $\mathrm{Ca} / \mathrm{SO}_{4}$ ratio and wellhead temperature of the geothermal and non-geothermal waters samples is shown in figure 11. Taking into consideration the distinctive values of $\mathrm{Ca} / \mathrm{SO}_{4}$ ratio of lower Cretaceous water (0.6 to 0.9 ) and Miocene water (0.2 to 0.4), these two mass waters could be assumed to be two end-members representing deep geothermal and shallow non-geothermal waters, respectively. Waters sampled from Upper Cretaceous aquifer are plotted on two subgroups on intermediate position between Miocene and Lower Cretaceous waters. Upper cretaceous subgroup 1 displays the same $\mathrm{Ca} / \mathrm{SO}_{4}$ ratio value of geothermal water resulting probably from the major contribution of CI groundwater, recharging the Jeffara aquifer. Samples within the subgroup 1 are placed between El HammaChenchou-Gabes axis and Matmata-Mareth, 


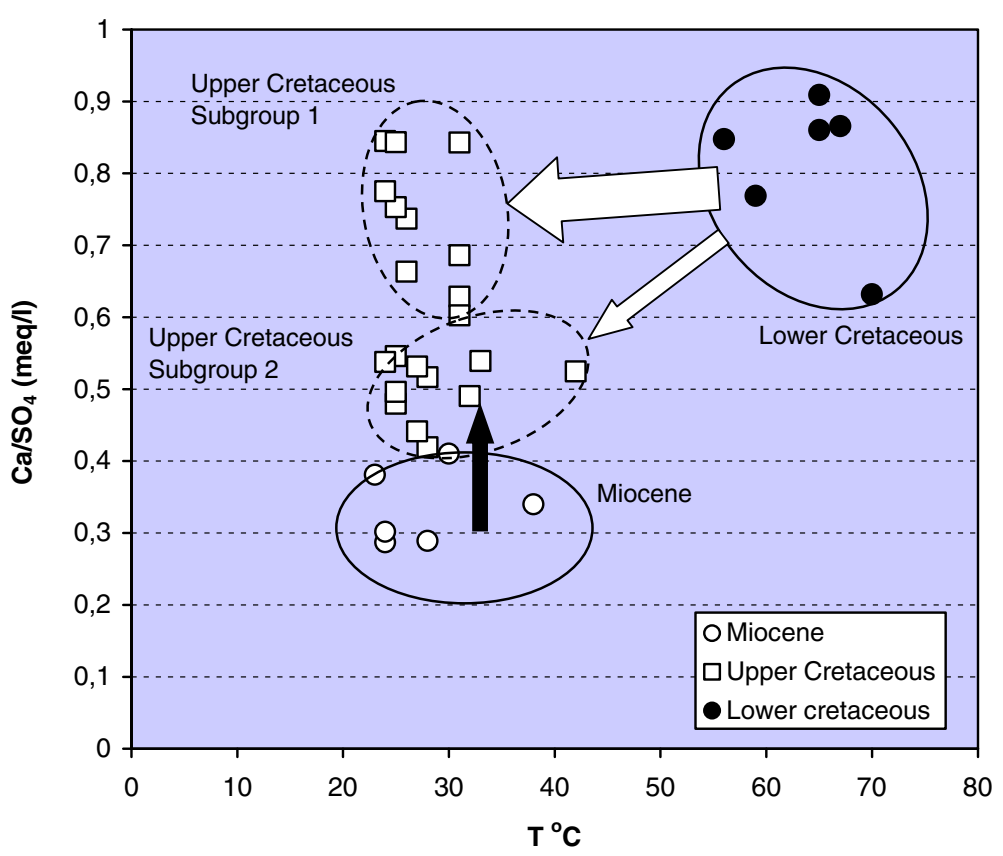

Figure 11. Ca/ $\mathrm{SO}_{4}$ versus water temperature, showing two lower Cretaceous and Miocene end-members. Upper Cretaceous presents two sub-groups related to the CI rate contribution, recharging the fissured limestone aquifer.

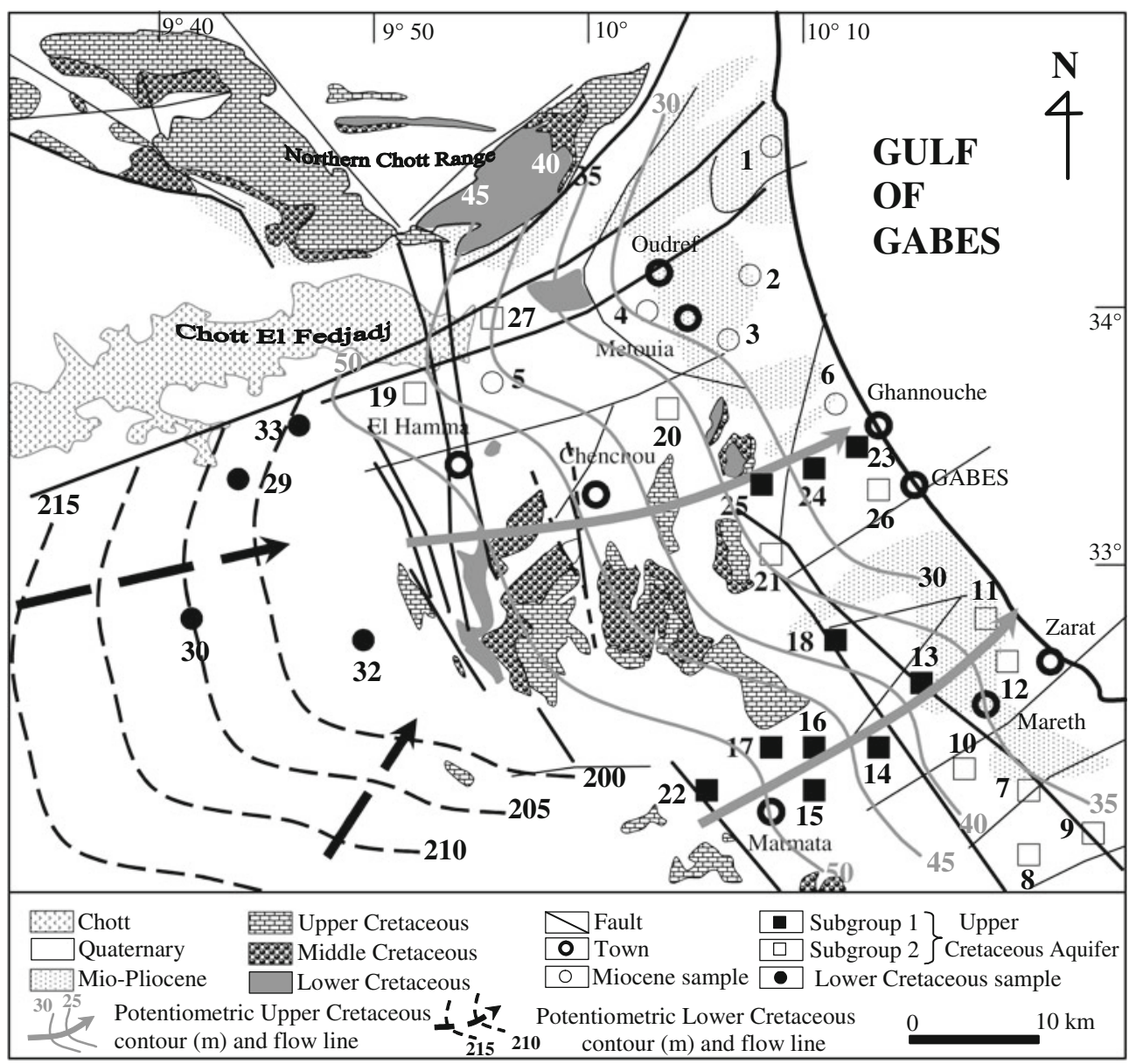

Figure 12. Potentiometric Lower and Upper Cretaceous surface contour showing preferential flow axes in relation to major faults in the study area. 
where the fault system is the most significant in the region.

Upper Cretaceous subgroup 2 occupies an intermediate position between the two end-members, reflecting the mixing ascent geothermal and surface water. The northern Chott range and the south Matmata-Mareth axis where fissured limestones of Senonian level outcrop, constitute the preferential local recharge by the downward rainy events from Matmata and Dahar reliefs (figure 12).

The mean concentration compounds in water representing the two end-members (Lower Cretaceous and Miocene) give a mixing ratio for the intermediate Upper Cretaceous water (using AquaChem 3.70/Mix samples) of about $40 \%$ for gypsum dissolution $\left(\mathrm{CaSO}_{4}\right)$. The same range computed contributions using isotopic model, varies from $29 \%$ to $53 \%$ (Trabelsi et al. 2009).

\section{Conclusion}

The structure 'in horst and graben', which is the main feature in the compartmentalization of the Jeffara aquifer, is mainly responsible for the hydraulic continuity between Turonian, Senonian and Miocene aquifer levels.

The faulted geological structure of the Jeffara aquifer system in the El Hamma region has played a major role in its recharge by the CI geothermal aquifer.

Piezometry, water temperatures as well as chemical and isotopic compositions, confirm the hydraulic continuity between these two aquifers (Trabelsi et al. 2009).

The hydrochemical characteristics of the Jeffara groundwater comprise two water types resulting mainly from evaporites dissolution. The $\mathrm{Ca}-\mathrm{Mg}-$ $\mathrm{SO}_{4}-\mathrm{Cl}$ main water type highlighted the predominance of the gypsum dissolution, largely spread into subsurface and deep in various forms; while, the second $\mathrm{Na}-\mathrm{Cl}$ water type results from halite dissolution, locally outcropping as a diapir, in the northern Chott Chain (Hadifa Mn.) and/or restricted contamination by saline lakes brine, in the vicinity of oases.

Bivariate diagrams of major elements confirm the dissolution of evaporites as a potential origin of the Jeffara water salinization.

The computed SI values showed that groundwater in the Jeffara aquifer was largely undersaturated with respect to halite, thenardite and mirabilite, to a lesser extent, with respect to anhydrite and gypsum, indicating possible dissolution of these minerals. These eventual dissolutions were confirmed by strong positive relationships between SI and ions resulting from the referred dissolutions for all three aquifers.
Solubility of anions and cations changes from the CI to the Jeffara aquifers (sulphate, strontium and magnesium increase, potassium decreases and sodium, calcium, chloride and bicarbonates show no content variation) without notable change in the water type. The constancy of water type for all the three aquifers, reflects the CI large contribution and/or the predominance of evaporate dissolution as the main process of water salinization. In the study area, abundant surface and buried gypsum reinforce this supposition.

The mixing rate inferred from $\mathrm{Ca} / \mathrm{SO}_{4}$ versus temperature shows that CI-contribution recharging upper fissured limestone aquifer occurs mainly between El Hamma-Chenchou and Mareth regions. Evaporite dissolution can be a significant process on a regional scale in carbonate aquifers and give rise to early high permeability groundwater flow paths that influence later aquifer development by the 'normal' process of carbonate dissolution (Gunn et al. 2006).

\section{Acknowledgements}

The authors are grateful to Dr Katarzyna Samborska and anonymous reviewers for their constructive remarks and criticisms which considerably improved the manuscript.

\section{References}

Abidi B 2004 Caractéristiques hydrodynamiques et géochimiques de la Jeffara de Gabès; Tech. Doc. DGRE, Tunis, p. 198.

Ben Ayed N 1986 Evolution tectonique de l'avant pays de la chaine alpine de Tunisie du début du Mésozoique à l'actuel; Thesis Univ. Paris Sud, Centre d'Orsay, France, p. 286.

Ben Baccar B 1982 Contribution à l'étude hydrogéologique de l'aquifère multicouche de Gabès Sud. Doctorat Thesis Paris Sud France, p. 115.

Ben Ouezdou H 1983 Etude morphologique et stratigraphique des formations quaternaires dans les alentours du Golfe de Gabès; Doctorat Thesis, Faculté des Sc. Humaines et Sociales, Tunis, p. 216.

Benton M, Bouaziz S, Buffetaut E, Martil D, Ouaja M, Soussi M and Trueman C 2000 Dinosaurs and other fossil vertebrates from fluvial deposits in the Lower Cretaceous of southern Tunisia; Palaeogeogr. Palaeoclimatol. Palaeoecol. 157 227-246.

Bouaziz S 1995 Etude de la tectonique cassante dans la plate-forme et l'Atlas saharien (Tunisie Méridionale): Evolution des paléochamps de contraintes et implications géodynamiques; Thesis, University of Tunis II. Faculty of Sciences of Tunis, Tunisia, p. 485.

Bouaziz S, Barrier E, Soussi M, Turki M M and Zouari H 2002 Tectonic evolution of the northern African margin in Tunisia from paleostress data and sedimentary record; Tectonophys. 357 227-253.

Bouri S, Makni J and Ben Dhia H 2008 A synthetic approach integrating subsurface and surface data for prospecting 
deep aquifers: the southeast Tunisia; Environ. Geol. 54 1473-1484.

Chadha D K 1999 A new diagram for geochemical classification of natural waters and interpretation of chemical data; Hydrogeol. J. 7 431-439.

Charfi S 2004 Contribution à l'étude hydrogéologique, hydrochimique et isotopique de la nappe de la Jeffara de Gabès; Master degree, Laboratory of Radio-Analysis and Environment, National School of Engineers of Sfax (Tunisia), p. 91.

DGRE 2009 Direction Générale des Ressources en Eau. Annuaire d'exploitation des nappes profondes de la Tunisie; DGRE Tunis, p. 373.

Edmunds W M, Shand P, Guendouz A H, Moula A, Mamou A and Zouari K 1997 Recharge characteristics and groundwater quality of the Grand Erg Oriental basin; Tech. Rep. Wd/97/46R, Vienna, p. 92.

Gabtni H, Mickus K L, Zouari H and Turki M M 2006 The location and nature of the Telemzan High-Ghadames basin boundary in southern Tunisia based on gravity and magnetic anomalies; J. African Earth Sci. 44 303-313.

Gemici U and Filiz S 2001 Hydrogeochemistry of the Cesme geothermal field, western Turkey; J. Volcanol. Geotherm. Res. 110 171-187.

Gonfiantini R, Conrad G, Fontes J C, Sauzy G and Payne B R 1974 Etude isotopique de la nappe du Continental Intercalaire et de ses relations avec les autres nappes du Sahara septentrional; In: Isotope techniques in groundwater hydrology, Proc. Symp. IAEA Vienna I, pp. 227241.

Guendouz A, Moula A S, Edmunds W M, Zouari K, Shand P and Mamou A 2003 Hydrogeochemical and isotopic evolution of water in the complexe terminal aquifer in the Algerian Sahara; J. Hydrol. 11 483-495.

Gunn J, Bottrell S H, Lowe D J and Worthington S R H 2006 Deep groundwater flow and geological processes in limestone aquifers: Evidence from thermal waters in Derbyshire, England, UK; Hydrogeol. J. 14868 881.

Kamel S, Dassi L, Zouari K and Abidi B 2005 Geochemical and isotopic investigation of the aquifer system in the Djerid-Nefzaoua basin, southern Tunisia; Environ. Geol. 49 159-170.
Kettata M, Hamzaoui F, Gueddari M, Bouhlila R and Ribeiro L 2009 Hydrochemical and statistical study of groundwaters in Gabes-south deep aquifer (south-eastern Tunisia); Phys. Chem. Earth 36 187-196.

Kinsman D J 1966 Gypsum and anhydrite of recent age, Crucial Coast, Persian Gulf; Proc. 2nd Salt Symp. Northern Ohio; Geol. Soc. 1 302-326.

Mamou A 1990 Caracteristiques et évaluation et gestion des ressources en eau du Sud Tunisien; Thesis Univ. Paris Sud France, p. 426.

Mamou M and Kassah A 2002 Eau et développement dans le sud tunisien; Cahiers du CERES, série géographique no. 23, Tunis, p. 268.

Mekrazi A F 1975 Contribution à l'étude géologique et hydrogéologique de la région de Gabès Nord; Thesis University of Bordeau I, France, p. 160.

Mhamdi A, Dhahri F, Gouasmia M, Inoubli N, Soussi M, and Ben Dhia H 2011 Groundwater investigation in the southern part of Gabes using resistivity sounding, southern Tunisia; Arab J. Geosci. (published online), p. 14.

Nicholson K 1993 Geothermal fluids: Chemistry and exploration techniques (Heidelberg, Berlin: Springer-Verlag), p. 262.

OSS (Observatoire du Sahara et du Sahel) 2003 Système aquifère du Sahara septentrional. Une conscience de bassin; Vol. II. Hydrogéologie. Observatoire du Sahara et du Sahel, p. 322.

Plummer L N, Prestmon E and Parkhurst D L 1992 An interactive code (netpath) for modelling net geochemical reaction along a flow path; Techniques of water resources investigations of US Geological Survey, p. 91.

Rouatbi R 1967 Contribution à l'étude hydrogéologique du karst enterré de Gabès; Sud. Thesis Doctorat Univ. Montpellier, France, p. 224.

Swezey C 2003 The role of climate in the creation and destruction of continental stratigraphic records: An example from the northern margin of the Sahara desert; SEPM (Society of Sedimentary Geology), Spec. Publ. 77 207-225.

Trabelsi R, Kassem A, Zouari K and Rozanski K 2009 Quantifying regional groundwater flow between Continental Intercalaire and Djeffara aquifers in southern Tunisia using isotope methods; Environ. Geol. 58 171-183. 